ENCYCLOPEDDIE Encyclopédie berbère

BERBERE

1 | 1984

1 | Abadir - Acridophagie

Abū Ya'qūb Yūsof

(Voir Almohades)

C. Agabi

\title{
OpenEdition
}

Journals

Édition électronique

URL : http://journals.openedition.org/encyclopedieberbere/1241

DOI : 10.4000/encyclopedieberbere.1241

ISSN : 2262-7197

Éditeur

Peeters Publishers

Édition imprimée

Date de publication : 1 novembre 1984

Pagination : 94

ISBN : 2-85744-201-7

ISSN : $1015-7344$

Référence électronique

C. Agabi, «Abū Ya'qūb Yūsof », Encyclopédie berbère [En ligne], 1 | 1984, document A32, mis en ligne le

01 décembre 2012, consulté le 05 octobre 2020. URL : http://journals.openedition.org/

encyclopedieberbere/1241; DOI : https://doi.org/10.4000/encyclopedieberbere.1241

Ce document a été généré automatiquement le 5 octobre 2020.

(c) Tous droits réservés 


\section{Abū Ya'qūb Yūsof}

\section{(Voir Almohades)}

\section{Agabi}

Deux souverains portent ce nom. Le premier fut almohade, le second mérinide. Abū Ya'qūb Yūsof - calife almohade fils et successeur d"Abd-el-Mūmin, fondateur de la dynastie almohade (1163-1184). Il commença par rétablir l'autorité almohade sur l'Espagne musulmane en luttant contre Ibn Mardaniš qui, avec l'appui des rois d'Aragon et de Castille, s'était constitué un royaume indépendant dans le Levante et l'Andalousie orientale. Des difficultés en Ifrīqiya où les habitants de Gafsa se sont révoltés permettent aux chrétiens d'Espagne de reprendre la lutte. Abū Ya'qūb conduit une expédition mais il meurt au cours du combat de Santarem.

\section{BIBLIOGRAPHIE}

Voir Almohades.

\section{INDEX}

Mots-clés : Espagne, Maroc, Moyen Âge 